\title{
PERANCANGAN DAN IMPLEMENTASI DATA WAREHOUSE UNTUK PERPUSTAKAAN KAMPUS (STUDI KASUS : STMIK ROSMA KARAWANG)
}

\section{DESIGN AND IMPLEMENTATION DATA WAREHOUSE FOR CAMPUS (CASE STUDY: STMIK ROSMA KARAWANG)}

\author{
Lila Setiyani ${ }^{1}$, Evelyn Tjandra ${ }^{2}$ \\ 1,2Program Studi Sistem Informasi, STMIK Rosma Karawang \\ lila.setiyani@dosen.rosma.ac.id
}

\begin{abstract}
Abstrak
Perpustakaan sebagai sebuah unit pelayanan dalam suatu kampus sangatlah penting untuk memberikan informasi dan pelayanan terbaik. Dengan semakin banyaknya koleksi perpustakaan maka semakin banyak pula berbagai data yang didapatkan perpustakaan. Agar data lama perpustakaan yang masih tersimpan dapat digunakan kembali pada saat dibutuhkan, maka memerlukan integrasi antara data baru dan data lama pada sistem perpustakaan. Data warehouse adalah konsep yang digunakan untuk mengintegrasikan data dalam penyimpanan sistem database perpustakaan. Terlebih lagi dibutuhkan informasi yang lengkap, cepat dan akurat bagi para tingkatan manajerial perpustakaan. Integrasi data dilakukan dengan melakukan ekstraksi dari sumber data dengan mengambil item data yang diperlukan. Hasil dari penelitian ini adalah data warehouse aplikasi perpustakaan yang dapat digunakan oleh perpustakaan STMIK Rosma Karawang dalam menyimpan data-data perpustakaaan dan dapat mempermudah dalam pengambilan keputusan perpustakaan karena sudah tersedianya penyimpanan data dalam bentuk data warehouse perpustakaan.
\end{abstract}

\section{Kata Kunci: Perpustakaan, Data Warehouse, Integrasi}

\begin{abstract}
The library, as a service unit on campus, is essential to provide the best information and services. With the increasing number of library collections, the more various data obtained by the library. So that old library data that is still stored can be reused when needed, it requires integration between new data and old data in the library system. A data warehouse is a concept used to integrate data in a library database storage system. Moreover, complete, fast, and accurate information is needed for library managerial levels. Data integration is done by extracting from data sources by taking the required data items. The results of this study are a library application data warehouse, which can be used by the STMIK
\end{abstract}


Rosma Karawang library in storing library data and can make it easier to make library decisions because data storage is available in the form of a library data warehouse.

\section{Keywords: Library, Data Warehouse, Integration}

\section{PENDAHULUAN}

Penggunaan sistem informasi pada perpustakaan memberikan dampak yang sangat baik untuk mempermudah pendataan buku, proses transaksi peminjaman dan pengembalian buku, serta membantu mempermudah pelaporan kepada manajemen perpustakaan. Untuk meningkatkan kualitas pelayanan pada perpustakaan, maka perpustakaan terus mengembangkan sistem data base. Konsep data warehouse menjadi alternatif untuk mengembangkannya, data warehouse digunakan untuk mengintegrasikan data lama dan data baru perpustakaan tanpa harus melakukan entri data ulang.

Sampai saat ini data warehouse terus berkembang dan tumbuh menjadi suatu kebutuhan dalam suatu perusahaan, organisasi dan bisnis. Teknologi data warehouse dibutuhkan oleh sebagian besar organisasi atau perusahaan, yang mana memungkinkan untuk melakukan integrasi beberapa macam data lama dan data baru agar tidak terjadi duplikasi data dan menganalisis berbagai data histori yang berasal dari berbagai sistem dan aplikasi dalam satu tempat penyimpanan yang besar. Data yang telah diintegrasikan dapat diolah dalam berbagai bentuk laporan sesuai dengan kebutuhan.
Proses data sebelum dilakukan loading (memasukkan data ke data warehouse) terlebih dahulu dilakukan ekstraksi data (extraction) yaitu proses mendapatkan data dari sumber data (source system). Setelah data diekstrak, kemudian dilakukan transformasi (transformation) yaitu proses mengkonversi data ke dalam bentuk yang bermanfaat untuk analisis. Untuk lebih jelasnya proses integrasi data yang meliputi ekstraksi, transformasi dan loading seperti pada gambar dibawah ini:

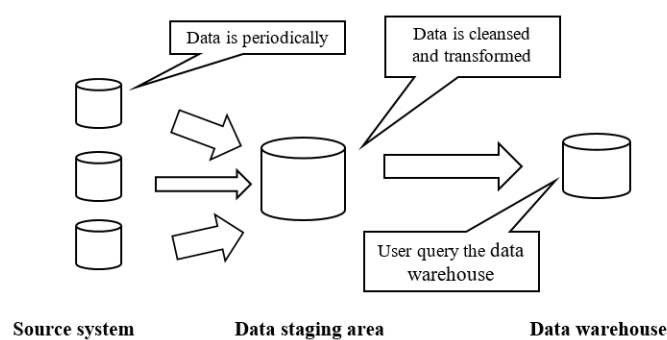

Gambar 1. Proses Integrasi Data ke Dalam Data Warehouse (Safril, 2009)

Tujuan dari penelitian ini adalah merancang Data Warehouse perpustakaan pada perpustakaan STMIK Rosma Karawang. Adapun kontribusi penelitian ini adalah meningkatkan pemanfaatan teknologi informasi terutama teknologi penyimpanan dalam pengembangan sebuah aplikasi yang 
ada dalam perpustakaan yang dapat mempermudah dalam proses pelaporan dan analisis.

\section{LANDASAN TEORI \\ Perpustakaan}

Secara tradisional arti dari perpustakaan adalah sebuah koleksi buku dan majalah. Walaupun dapat juga diartikan sebagai koleksi pribadi perseorangan namun lebih umum dikenal sebagai sebuah koleksi besar yang dibiayai dan dioperasikan oleh sebuah kota atau institusi yang dimanfaatkan oleh masyarakat yang rata-rata tidak mampu membeli sekian banyak buku ata sbiaya sendiri (Rokan, 2017). Menurut undang-undang nomor 43 tahun 2007 menyatakan pada pasal 1 ayat 1 dalam (Yusup et al., 2016), bahwa "Perpustakaan adalah institusi pengelola koleksi karya tulis, karya cetak, dan/atau karya rekam secara profesional dengan sistem yang baku guna memenuhi kebutuhan pendidikan, penelitian, pelestarian, informasi, dan rekreasi para pemustaka". Sementara itu pada ayat 2 dikemukakan bahwa yang dimaksud dengan "koleksi perpustakaan adalah semua informasi dalam bentuk karya tulis, karya cetak, dan/atau karya rekam dalam berbagai media yang mempunyai nilai pendidikan, yang dihimpun, diolah, dan dilayankan', kepada masyarakat tanpa membeda-bedakan status sosialnya, baik pada generasi sekarang maupun pada generasi yang akan datang.
Perpustakaan lebih dikenal secara umum sebagai sebuah koleksi besar yang dibiayai dan dioperasikan oleh sebuah kota atau institusi. Perpustakaan dapat dimanfaatkan oleh masyarakat yang rata-rata tidak mampu membeli buku dengan biaya sendiri dengan melakukan pinjaman. Peminjaman buku biasanya dilakukan oleh member yang sudah terdaftar pada perpustakaan untuk menghindari hal-hal yang tidak diinginkan. Pustakawan juga perlu mendata buku, member dan data peminjaman. Peminjaman yang dilakukan oleh member harus mengikuti ketentuan-ketentuan yang diberlakukan oleh pustakawan. Misalnya dikenakan sanksi jika terjadi keterlambatan pengembalian atau kerusakan pada buku.

\section{Basis Data}

Basis data (database) merupakan kumpulan data yang saling berhubungan satu dengan yang lainnya, dan merupakan elemen yang paling penting dalam suatu sistem informasi, karena basis data adalah dasar ataupun tempat menyediakan informasi bagi para pemakai.

Menurut Connoly dan Begg, (2010) dalam (Puspitasari et al., 2016) mengatakan basis data adalah kumpulan data yang saling berhubungan secara logikal serta deskripsi dari data tersebut, yang dirancang untuk memenuhi 
kebutuhan informasi suatu organisasi .

Oetomo (2002) dalam (Sitorus \& Simbolon, 2016) mengatakan basis data merupakan komponen terpenting dalam pembangunan sistem informasi karena menjadi tempat untuk menampung dan mengorganisasikan seluruh data yang ada dalam sistem, sehingga dapat dieksplorasikan untuk menyusun informasi-informasi dalam berbagai bentuk. Hirarki/tingkatan data dalam database:

1. Database Management System (DBMS), diartikan sebagai suatu program komputer yang digunakan untuk memasukkan, mengubah, memanipulasi dan memperoleh data atau informasi dengan praktis dan efisien.

2. Database, merupakan kumpulan file yang saling terkait satu sama lain.

3. File, merupakan kumpulan dari record yang saling terkait dan memiliki format field yang sama dan sejenis.

4. Record, merupakan kumpulan atribut field yang menggambarkan suatu unit data individu tertentu.

5. Field, merupakan kumpulan atribut dari record yang menunjukkan suatu item dari data seperti nama, alamat.

6. Byte, merupakan atribut dari field yang berupa huruf yang membentuk nilai dari sebuah field.

\section{Data Warehouse}

Menurut Inmondan Richard D.H (1994) dalam (Tujni et al., 2017) data Warehouse adalah koleksi data yang mempunyai sifat berorientasi subjek, terintegrasi, time-variant, dan bersifat tetap dari kumpulan data dalam mendukung proses pengambilan keputusan manajemen. Menurut Vidette Poe (1997) dalam (Bakhri \& Yamin, 2018), data Warehouse merupakan database yang bersifat analisis dan read only yang digunakan sebagai fondasi dari sistem penunjang keputusan. Data Warehouse merupakan database relasional yang didesain lebih kepada query dan analisis daripada proses transaksi, biasanya mengandung history data dari proses transaksi dan bisa juga data dari sumber lainnya. Data Warehouse adalah kumpulan data-data logik yang terpisah dengan database operasional dan merupakan suatu ringkasan. Karakteristik data Warehouse terdiri dari:

1. Berorientasi Subyek

Data Warehouse adalah tempat penyimpanan berdasakan subyek bukan berdasakan aplikasi. Subyek merupakan bagian dari suatu perusahaan. Contoh subyek pada perusahaan manufaktur adalah penjualan, konsumen, inventori, daln lain sebagainya. Gambar dibawah ini merupakan perbedaan mengenai data Warehouse dan database operasional.

2. Data yang terintegrasi 
Sumber data yang ada dalam data Warehouse tidak hanya berasal dari database operasional (internal source) tetapi juga berasal dari data diluar sistem (external source). Data pada sumber berbeda dapat diencode dengan cara yang berbeda.

\section{Nonvolatile}

Data dalam database operasional akan secara berkala atau periodik dipindahkan kedalam data Warehouse sesuai dengan jadwal yang sudah ditentukan. Misal perhari, perminggu, perbulan, dan lain sebagainya. Sekali masuk ke dalam data Warehouse, data adalah readonly.

\section{Time-Variant}

Sistem operasional mengandung data yang bernilai sekarang sedangkan data dalam data Warehouse mengandung data tidak hanya data terkini tetapi juga data history yang akan digunakan dalam analisis dan pengambilan keputusan. Waktu adalah dimensi penting yang harus didukung oleh semua data Warehouse. Data untuk analisis dari berbagai sumber berisi berbagai nilai waktu, misalkan harian, mingguan, dan bulanan.

5. Ringkas

Jika diperlukan, data operasional dikumpulkan ke dalam ringkasanringkasan.

\section{Granularity}

Pada sistem operasional data dibuat secara real-time sehingga untuk mendapatkan informasi langsung dilakukan proses query. Pada data Warehouse pada menganalisis harus memperhatikan level-ofdetail misalkan perhari, ringkasan perbulan, ringkasan pertigabulan.

7. Tidak ternormalisasi

Data di dalam sebuah data Warehouse biasanya tidak ternormalisasi dan sangat redundan.

Menurut Mallach (2000) Data Warehouse mengandung beberapa elemen penting antara lain (Hilman \& Djamaludin, 2018):

1. Sumber data yang digunakan oleh data Warehouse, database transaksional dan sumber data eksternal.

2. Proses ETL (Extraction, Transformation, Loading) dari sumber data ke database data Warehouse.

3. Membuat suatu ringkasan atau summary terhadap data Warehouse misalkan dengan menggunakan fungsi agregat.

4. Metadata, metadata mengacu data tentang data. Metadata menguraikan struktur dan beberapa arti tentang data, dengan demikian mendukung penggunaan efektif atau tidak efektif dari data.

5. Database data Warehouse. Database ini berisi data yang detail dan ringkasan data dari data 
yang ada di dalam data Warehouse. Karena data Warehouse tidak digunakan dalam proses transaksi individu, maka databasenya tidak perlu diorganisasikan untuk akses transaksi dan untuk pengambilan data, melainkan dioptimisasikan untuk pola akses yang berbeda di dalam analisis.

6. Query Tools yaitu dengan OLAP (Online Analytical Processing) dan data mining. Tool untuk query ini meliputi antarmuka pengguna akhir dalam mengajukan pertanyaan kepada database, dimana proses ini disebut sebagai Online Analytical Processing (OLAP). Tool ini juga terdiri dari tool otomatis yang menemukan pola-pola di dalam data, yang sering disebut sebagai data mining. Data Warehouse harus memiliki salah satu dari kedua tipe ini atau malah keduaduanya.

7. User, merupakan pengguna yang memanfaatkan data Warehouse tersebut.

\section{METODE PENELITIAN}

Data sumber yang digunakan dalam penelitian ini berupa basis data perpustakaan yang sudah dirancang sesuai dengan bisnis proses pada sistem perpustakaan pada umumnya. Objek dari penelitian ini adalah data anggota/mahasiswa, pegawai, buku dan data peminjaman yang akan dilakukan ekstraksi kedalam data warehouse. Gambaran umum dari penelitian mengenai implementasi data warehouse untuk analisis peminjaman buku pada perpustakaan dapat dilihat pada Gambar 2 dibawah ini.

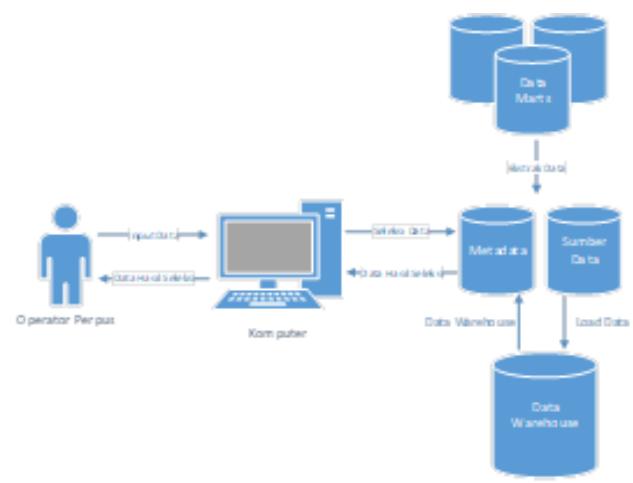

Gambar 2. Gambaran Umum Aplikasi

Tahap awal sistem dimulai dari memasukkan data dari database sumber ke aplikasi. Data dari database sumber dilakukan proses ETL dalam aplikasi sehingga menghasilkan Data Warehouse dan dimasukkan ke database data warehouse. Pengguna dapat memasukkan data seleksi seperti tahun dan bulan kedalam aplikasi, lalu aplikasi menyeleksi data dari Data Warehouse kemudian memberikan output Data Hasil Seleksi ke sistem dan diterima oleh Pengguna.

\section{ANALISIS DAN DESAIN Analisis Kebutuhan}

Analisis kebutuhan dilakukan melalui pengumpulan data berupa dokumen yang digunakan untuk membangun data warehouse. Dari analisis kebutuhan system akan 
didapatkan informasi apa yang diperlukan untuk pengembangan data warehouse. Kebutuhan Pengguna Pegawai Perpustakaan adalah sebagai berikut.

1. Admin dapat mengelola data pengguna.

2. Admin dapat mengelola data anggota.

3. Admin dapat mengelola data buku.

4. Admin dapat melakukan pengajuan buku.

5. Admin dapat Mencatat Penerimaan Buku.

6. Admin dapat mengelola data Peminjaman.

7. Admin dapat mengelola data Pengembalian.

8. Admin dapat mengelola laporan.

\section{Desain Data Warehouse}

Sebagai gambaran umum proses alur dari dari masukan, proses dan keluaran data seperti uraian berikut ini:

1. Arsitektur Data Warehouse

Desain arsitektur data warehouse yang dibangun terdiri tiga bagian yang liputi sumber data, data warehouse dan cara akses bagi pengguna seperti pada gambar 1 . Meliputi sumber data eksternal, proses data dan keluaran data.
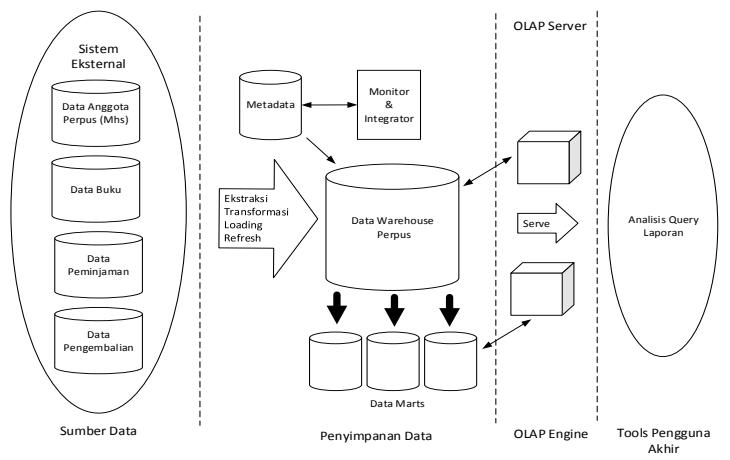

Gambar 3. Arsitektur Data

Warehouse

2. Aktivitas pada Sistem

Rancangan aktifitas pada sistem perlu dilakukan untuk mengetahui kegiatan dan komponen apa saja yang berkaitan dengan sistem perpustakaan STMIK Rosma. Untuk lebih jelasnya kegiatan dan aktifitas apa saja yang terlibat dalam proses yang terjadi di perpustakaan dapat digambarkan diagram pada diagram konteks. Diagram konteks merupakan diagram yang menggambarkan kondisi system yang baik input maupun output pada system serta menyatakan terminator yang terlibat dalam penggunaan system. Diagram ini akan memberikan gambaran tentang keseluruhan sistem. Berikut pada diagram konteks perpusataakn disajikan pada Gambar 4. 


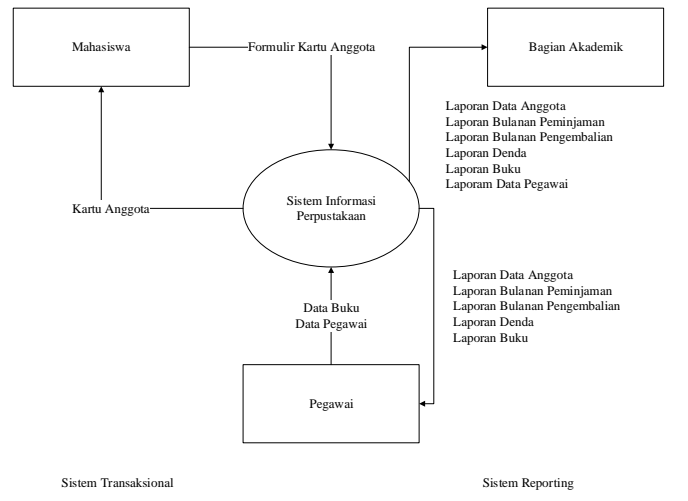

Gambar 4. Diagram Konteks Perpustakaan

\section{Penyusunan Diagram Snowflake} Snowflake schema adalah jenis dari skema bintang dimana tabel dimensinya tidak mengandung denormalisasi. Dapat diartikan bahwa bahwa tabel fakta pada star schema dikelilingi oleh banyak dimensi dengan hubungan one-tomany, sedangkan pada snowflake tabel fakta terhubung banyak ke tabel dimensi, yang dimana dimensi tersebut dapat dihubungkan ke tabel dimensi lain (Gunaya et al., 2019). Dalam tahapan ini kegiatan yang dilakukan adalah membuat model data dimensional yang berbentuk snowflake schema dan dilanjutkan membuat rancangan proses ETL. Yang menjadi subyek utama dalam warehouse perpustakaan adalah sirkulasi peminjaman buku untuk mahasiswa yang akan menjadi pusat skema. Model rancangan snowflake schema tersebut dapat dilihat pada Gambar 5 berikut ini:

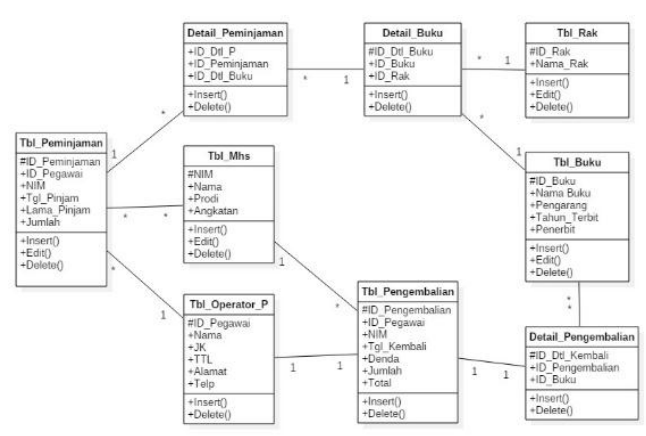

Gambar 5. Diagram Snowflake

\section{HASIL IMPLEMENTASI}

Pada bagian ini disajikan hasil dari implementasi sistem aplikasi transakasi perpustakaan.

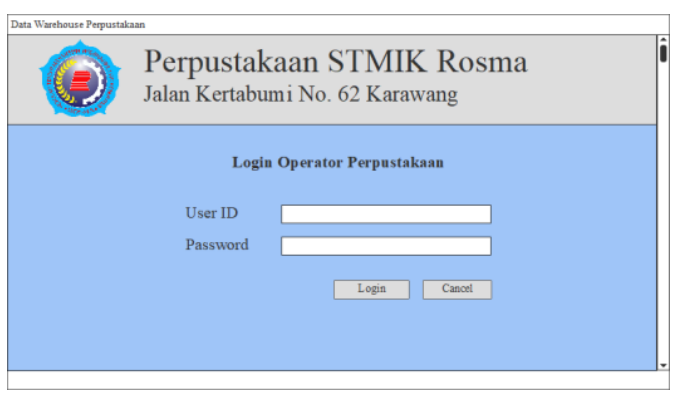

Gambar 6. Halaman Login Admin Perpustakaan

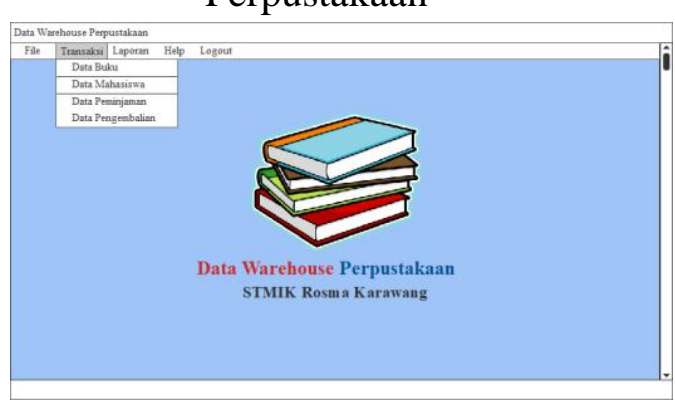

Gambar 7. Tampilan Halaman Awal Aplikasi Perpustakaan 


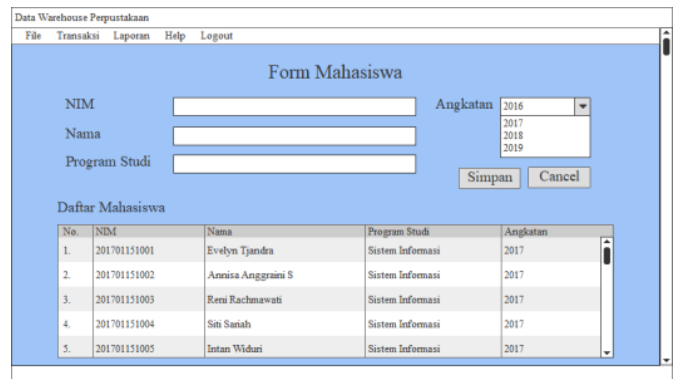

Gambar 8. Tampilan Form

Mahasiswa/Anggota Perpustakaan

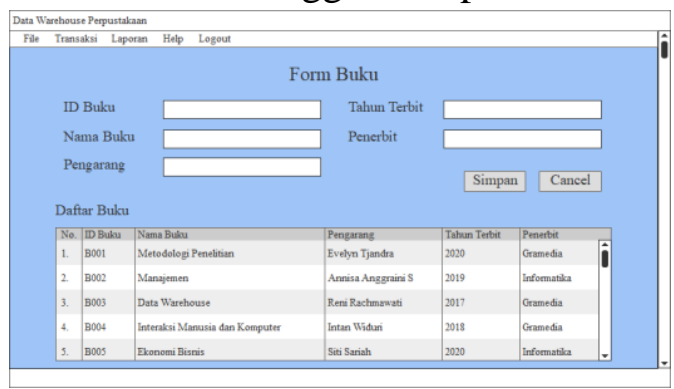

Gambar 9. Tanpilan Form Buku

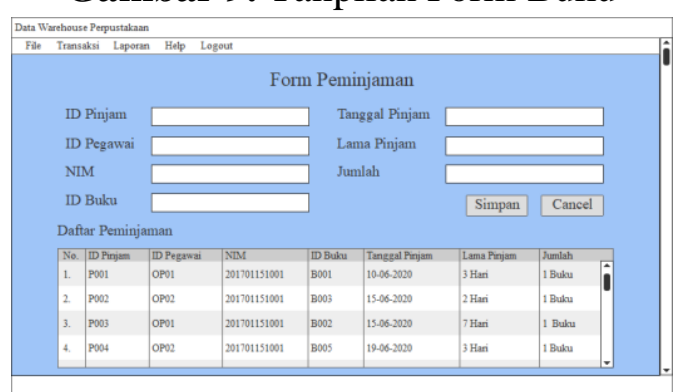

Gambar 10. Tampilan Form

Peminjaman

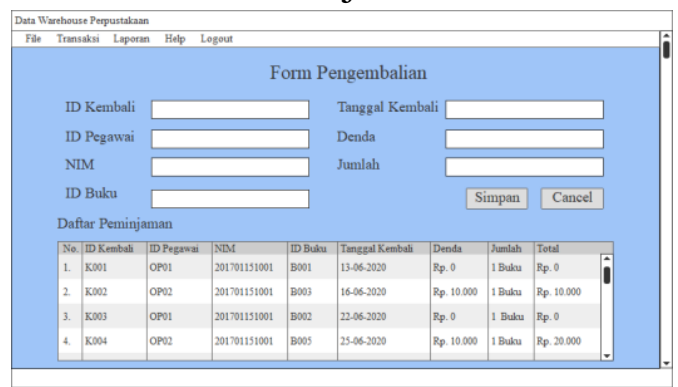

Gambar 11. Tampilan Form Pengembaliaan

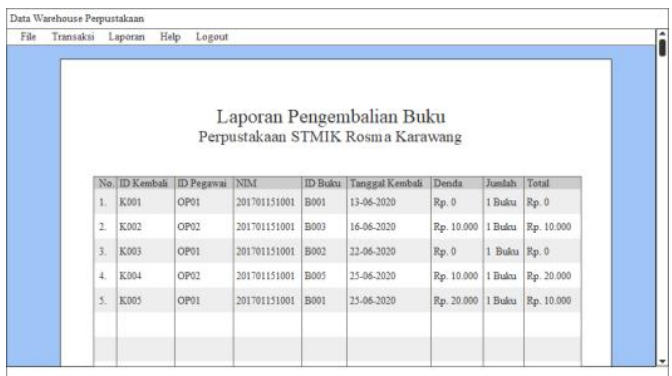

Gambar 12. Contoh Tampilan

Laporan Pengembalian Buku

\section{KESIMPULAN}

Kesimpulan yang didapat dari penelitian ini meliputi:

1. Penelitian ini menghasilkan sebuah rancangan data Warehouse perpustakaan yang dapat digunakan oleh perpustakaan STMIK Rosma Karawang dalam menyimpan data-data perpustakaaan.

2. Implementasi dari perancangan Data Warehouse dapat diterapkan dalam menyimpan koleksi-koleksi yang ada dalam perpustakaan.

3. Dengan adanya perancangan data warehouse ini akan mempermudah dalam pengembangan aplikasi-aplikasi pengambilan keputusan perpustakaan karena sudah tersedianya rancangan penyimpanan data dalam bentuk data warehouse perpustakaan.

4. Data Warehouse yang telah dibangun dapat digunakan pihak yang berkepentingan untuk dapat digunakan kembali dalam 
pengembangannya menggunakan perangkat lunak tertentu dalam menghasilkan sebuah informasi untuk pengambilan keputusan.

5. Standar perancangan yang digunakan dalam penelitian ini adalah snowflake schema, penggunaan skema ini terbukti dapat meningkatkan performa dan dan kemudahan dalam penterjemahan ke sistem OLAP.

\section{SARAN}

Berikut ini adalah kekurangan dalam penelitian ini yang diharapkan dapat menjadi bahan masukan atau saran untuk peneliti selanjutnya:

1. Penentuan objek database sebagai data source harus diperhatikan secara matang. Database yang memiliki integritas data yang baik akan memudahkan dalam pembangunan data warehouse.

2. Karena keterbatasan waktu dalam pengerjaan penelitian ini, maka diharapkan peneliti selanjutnya dapat mengembangkan hasil dari penelitian ini.

3. Dari analisis tersebut, selanjutnya bisa dilakukan penelitian untuk membangun analysis service.

\section{DAFTAR PUSTAKA}

Bakhri, S., \& Yamin, Y. N. (2018). RANCANGAN DATA WAREHOUSE UNTUK PENUNJANG SISTEM INFORMASI EKSEKUTIF PADA
YAYASAN UMMU'L QURO DI DEPOK. Jurnal Teknik Komputer, $\quad 4(1)$. https://doi.org/https://doi.org/1 $0.31294 /$ jtk.v4i1.2498

Gunaya, I. W., Jhonarendra, P., Deva, I. P., \& Putra, J. (2019). Implementasi Data Warehouse untuk Analisis Peminjaman Buku pada Implementasi Data Warehouse untuk Analisis Peminjaman Buku pada Perpustakaan. April, 0-11.

Hilman, M., \& Djamaludin, D. (2018). Analisis Faktor Optimalisasi Proses Etl Pada Data Warehouse Sebagai Pendukung Pengambilan Keputusan Management Dengan Business Intelligence. Faktor Exacta, 11(1), 24-34. https://doi.org/10.30998/faktor exacta.v11i1.2325

Puspitasari, D., Studi, P., \& Informatika, M. (2016). Sistem informasi perpustakaan sekolah berbasis web. 2, 227240.

Rokan, M. R. (2017). Manajemen perpustakaan sekolah. Jurnal Iqra', 11(01), 1-14.

Safril, A. (2009). PERANCANGAN DAN IMPLEMENTASI DATA WAREHOUSE

METEOROLOGI, KLIMATOLOGI, GEOFISIKA DAN BENCANA ALAM. 10(2), 133-144.

Sitorus, L., \& Simbolon, T. R. R. (2016). Implementasi Data Warehouse pada Perpustakaan Universitas Katolik Santo 
Thomas Sumatera Utara Abstrak Sistem Informasi Perpustakaan. 01, 1-6.

Tujni, B., Universitas, D., Darma, B., Jenderal, J., Yani, A., \& Palembang, N. (2017). Perancangan data warehouse perpustakaan. Jurnal Ilmiah MATRIK, 19(2), 101-110.

Yusup, P. M., Winoto, Y., \& Rejeki, D. S. (2016). Kontribusi Perpustakaan Desa Dan Perpustakaan Masyarakat Dalam Pendiseminasian Sumber-Sumber Informasi Budaya Lokal. Prosiding Komunikasi, 9-21. http://jurnal.fisip.unila.ac.id/index .php/prosidingkom/article/viewFil $\mathrm{e} / 216 / 116$ 